\title{
Vegetation responses following wildfire on grazed and ungrazed sagebrush semi-desert
}

\author{
NEIL E. WEST AND TERENCE P. YORKS
}

Authors are Professor and Research Associate, respectively, Department of Rangeland Resources, Utah State University, Logan, Utah 84322-5230.

Abstract

A 20-year set of cover data on sagebrush semi-desert plant communities responding to wildfire and livestock grazing near Mills in central Utah provided an opportunity to compare the assumptions and adaptability of classical and state-and-transition models for describing secondary succession. Cover data were organized and analyzed by plant species, growth forms, and other ground cover classes. Graphical analysis, ordination (employing semi-strong hybrid multi-dimensional scaling), regression, and analysis-of-variance were used to determine whether the patterns observed were best described as community change (tightly linked species) or individualistic change (each species acting independently). Distinct differences in total plant cover, growth form, and species composition were found between burned (both grazed and ungrazed) and the unburned and grazed treatments. Conventional graphical and statistical analyses of burned and ungrazed plots showed greater and earlier expansion of perennial grasses and then relatively less coverweighted compositional change in recent years compared to the other treatments. Vegetation on none of the treatments appears to have stabilized toward either the pre-burn sagebrush semidesert, a new state or the potential natural community for the site involved. Pathways of change reflected in the ordinations have been complex in all treatments. The only obvious trends in responses of individual species were to fire and the inverse relationship of cheatgrass to total perennial vegetational cover. All this evidence points to few tight linkages between species or growth form groups and thus favors viewing these patterns individualistically. While the state-and-transition model allows greater flexibility than the classical model in the depiction of plant community/individual species changes consequent to any management action, it doesn't apply readily everywhere, as exemplified by this case study.

Key Words: community dynamics, Clementsian model, stateand-transition model, ordination, trend, condition

Research was funded by the Utah Agricultural Experiment Station of which this journal is Paper No. 7289. This research would have not been possible without permission from previous landowners as well as the current land owner, Ben Gambino. Also, a long list of students and the West family helped in annually collecting the data. All data and ancillary records are deposited in the Archive Section of the Merrill Library at Utah State University. Special thanks go to Susan Durham and Jim Haefner for advice on analysis methods.

Manuscript accepted 13 Apr. 01.

\section{Resumen}

Un juego de datos de 20 años sobre cambios de la cobertura vegetal de comunidades semidesérticas de "Sagebrush" en respuesta a fuegos naturales $y$ apacentamiento de ganado de áreas cerca de Mills, en la parte central de Utah, dieron una oportunidad para comparar los supuestos y la adaptabilidad de los modelos clásicos y los de estado y transición para describir la sucesión secundaria. Los datos de cobertura fueron organizados $y$ analizados por especies de plantas, formas de crecimiento y otras clases de cobertura de suelo. El análisis gráfico, la ordenación (empleando un híbrido semi-fuerte de escalamiento multidimensional), el análisis de varianza y regresión se utilizaron para determinar si los patrones observados fueron los mejores para describir como cambia la comunidad (especies fuertemente ligadas) y los cambios individualísticos (cada especie actuando individualmente). Se encontraron distintas diferencias entre los tratamientos de quema (ambos, apacentados y sin apacentar) y los sin quema y apacentados, diferencias respecto a la cobertura vegetal total, la forma de crecimiento y la composición de especies. Los análisis gráficos y estadísticos convencionales de las parcelas quemadas y sin apacentar mostraron una expansión mayor y mas temprana de los zacates perennes y por lo tanto un cambio relativamente menor de composición ponderada por cobertura en los años recientes comparado con otros tratamientos. En ninguno de los tratamientos la vegetación parece haberse estabilizado hacia las condiciones previas a la quema del "Sagebrush" semidesértico, un nuevo estado o la comunidad natural potencial del sito involucrado. Las rutas de cambio reflejadas en los ordenamientos han sido complejas en todos los tratamientos. Las unicas tendencias obvias en las respuestas de las especies individuales fueron al fuego y la relación inversa del "Cheatgrass" con la cobertura vegetal total perenne. Toda esta evidencia apunta a unos pocos vínculos fuertes entre grupos de especies o formas de crecimiento y de este modo favorece el ver estos patrones enforma individual. Mientras el modelo de estado y transición permite una mayor flexibilidad que el modelo clásico en la representación de los cambios de especies individuales o comunidades en consecuencia de cualquier acción de manejo, este no aplica fácilmente en todas partes, como se ejemplifica en este caso.

Basic ecologists, beginning about 1958, have rejected the linear, gradual, deterministic and reversible model of succession to climax (called the "classic" model here) associated with F.E. Clements (Burrows 1990). Rangeland ecologists slowly accepted this situation and have been searching for a replacement theory (Lauenroth and Laycock 1989) and a more modern means to 
monitor rangeland trend and judge condition (West and Smith 1997). Some (e.g. Laycock 1991, 1995) think that the stateand-transition model (Westoby et al.1989a) will be that replacement. Joyce (1993), however, cautions the profession not to abandon older ways of applying successional theory to the monitoring of trend and assessment of condition until we have adequate means of operating within a new theoretical framework. Scarnecchia (1995) persuasively argues that theory and methods should not be intimately linked if the profession is to mature. Both theory and methods will continue to evolve independently anyway.

The classic successional model is based on a mechanical metaphor (Botkin 1990), the static concept of stability (lack of change unless disturbed), and an ability to return to the previously defined single state of constancy (climax) after disturbance (Joyce 1993). The classic model assumes tight linkages between species and positive feedback of plants in changing microclimate and soils (facilitation) and advocates steady, unidirectional change toward climax. The state-and-transition model (Westoby et al. 1989a, 1989 b) implies that plant community composition makes dramatic changes only during times of unusual environmental influences. Furthermore, the species composition of differing plant communities in particular states, on a particular ecological site, fluctuate within defined limits (Treshow and Allan 1985), which can also be expressed as several domains of attraction, or boundedness (Lewontin 1969, Friedel 1991, Crowley 1992), depending on the degree of responses to disturbance.

Most modern observers consider the longer-term, directional differences between species presence and abundances within stands of vegetation occupying the same ecological sites and enduring similar treatments to indicate individualistic change (uncoordinated temporal changes by individual plant species in a particular community). While the state-and-transition model is capable of depicting either individualistic or co-ordinated compositional change, an examination of data in light of the manager's needs should indicate the favored perspective in particular circumstances.

How is a rangeland technician/manager to go about monitoring with this swirl of scientific and technological change about him or her? Rather than just considering these needs abstractly, we find it useful to work with case studies and analyze data in alternative ways. The following reviews how a 20-year interannual set of data on plant community and soil surface exposure in a sagebrush semi-desert area changed after wildfire. Some of the plots were subsequently grazed, but other plots were protected from livestock grazing. We will compare the responses in these differing treatments with competing theoretical and analytical frameworks.

Our objective was to opportunistically examine changes in vegetation cover and bare soil in a Utah instance and compare the assumptions and adaptability of classical and newer models of secondary succession. In particular, we wished to compare data organized by plant species, growth forms and other ground cover classes, analyzed by statistical, graphical and ordinational techniques. The literature led us to expect that alternate stable states would be created by wildfire, particularly when followed by livestock grazing. Detection of the several putative stable states was expected to be most easily discerned by ordination. We also expected that there would be evidence of tight rather than loose or no connections between species and growth forms as they replaced each other over time.

\section{Materials and Methods}

The study site is located on privatelyowned land $7.9 \mathrm{~km}$ west of the village of Mills, Juab Co. in central Utah $\left(39^{\circ} 29^{\prime} \mathrm{N}\right.$, $\left.112^{\circ} 7^{\prime} \mathrm{W}\right)$ on a dissected fan remnant or

Table 1. The 3 plant species contributing the greatest average cover in each of 5 lifeform classes at our study site.

\begin{tabular}{|c|c|c|c|}
\hline Lifeform & Rank 1 & Rank 2 & Rank 3 \\
\hline Perennial grasses & $\begin{array}{l}\text { bluebunch wheatgrass } \\
\text { Pseudoroegneria } \\
\text { spicata (Pursh) A. Löve } \\
\text { ssp. spicata }\end{array}$ & $\begin{array}{l}\text { Indian ricegrass } \\
\text { Achnatherum } \\
\text { hymenoides (Roemer \& } \\
\text { J.A. Schultes) Barkworth }\end{array}$ & $\begin{array}{l}\text { Sandberg bluegrass } \\
\text { Poa secunda J. Presl }\end{array}$ \\
\hline $\begin{array}{l}\text { Annual } \\
\text { grasses }\end{array}$ & $\begin{array}{l}\text { cheatgrass } \\
\text { Bromus tectorum } \mathrm{L} \text {. }\end{array}$ & & \\
\hline Shrubs & $\begin{array}{l}\text { Wyoming big sagebrush } \\
\text { Artemisia tridentata Nutt. ssp. } \\
\text { wyomingensis } \\
\text { Beetle \& Young }\end{array}$ & $\begin{array}{l}\text { Nevada jointfir (or } \\
\text { Mormon tea) } \\
\text { Ephedra nevadensis } \\
\text { S. Wats.) }\end{array}$ & $\begin{array}{l}\text { yellow rabbitbrush } \\
\text { Chrysothamnus } \\
\text { viscidiflorus } \\
\text { (Hook.) Nutt. }\end{array}$ \\
\hline Annual forbs & $\begin{array}{l}\text { Russian thistle } \\
\text { Salsola kali } \mathrm{L} \text {. }\end{array}$ & $\begin{array}{l}\text { northern tansymustard } \\
\text { Descurainia sophioides } \\
\text { (Fisch. ex Hook.) } \\
\text { O.E. Schulz }\end{array}$ & $\begin{array}{l}\text { prickly lettuce } \\
\text { Lactuca serriola L. }\end{array}$ \\
\hline Half-shrubs & $\begin{array}{l}\text { broom snakeweed } \\
\text { Gutierrezia sarothrae } \\
\text { (Pursh) Britt. \& Rusby }\end{array}$ & $\begin{array}{l}\text { granite prickly phlox } \\
\text { Leptodactylon pungens } \\
\text { (Torr.) Torr. ex Nutt. }\end{array}$ & $\begin{array}{l}\text { phlox } \\
\text { Phlox longifolia } \\
\text { Nutt. }\end{array}$ \\
\hline Perennial forbs & $\begin{array}{l}\text { mountain pepperweed } \\
\text { Lepidium montanum Nutt. }\end{array}$ & $\begin{array}{l}\text { sandwort } \\
\text { Arenaria fendleri } \\
\text { Gray }\end{array}$ & $\begin{array}{l}\text { fleabane } \\
\text { Erigeron argentatus } \\
\text { Gray }\end{array}$ \\
\hline
\end{tabular}

Plant name source: USDA, NRCS 1999. The PLANTS database (http://plants.usda.gov/plants). ballena (Peterson 1981) on the northeastern flank of the Canyon Mountains. Slopes are 1 to $2 \%$ east-facing, with elevations ranging between 1,617 and 1,622 meters $(5,305$ to 5,320 ft). Mean annual precipitation is about $300 \mathrm{~mm}$ and is, on average, concentrated from October to April. The mean annual air temperature is about $8^{\circ} \mathrm{C}$ (Trickler and Hall 1984).

Soils in the study area were mapped as Borvant cobbly loam, 2-8\% slopes (Trickler and Hall 1984). Profiles are mostly shallow, with less than $50 \mathrm{~cm}$ of calcareous, gravelly to very gravelly loam above a petrocalic horizon, which overlies stratified layers of gravelly loam and calcium carbonate-cemented material (Boettinger et al. 1997). These soils are classified as loamy-skeletal, carbonatic, mesic shallow Petrocalcic Paleoxerolls. The designated ecological site is Upland Shallow Loam (Juniper-Pinyon) with a potential natural community composed of $40 \%$ perennial grasses, $10 \%$ perennial forbs and $50 \%$ shrubs (by relative contribution to peak new growth phytomass) (Trickler and Hall 1984).

Vegetation at the study site immediately pre-burn and during the first 3 years of recovery following the wildfire of 26 July 1981 have been previously reported (West and Hassan 1985). This earlier paper also has further details about the fire. Since these responses to the pulse treatment of the fire were likely transitory (Tilman 1988), subsequent vegetational change was of continuing interest. Table 1 lists 
Plots
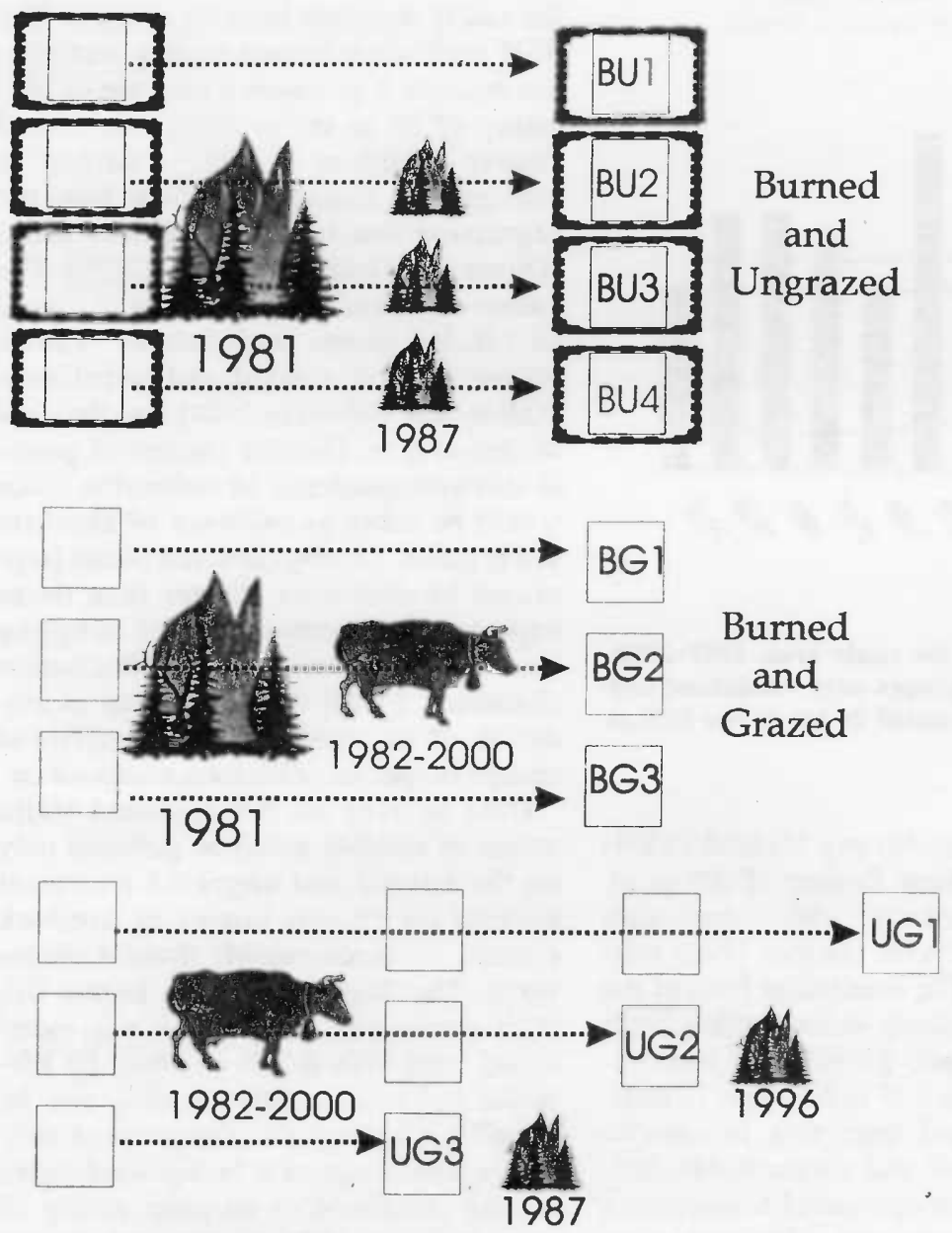

Fig. 1. Summarization of disturbance history for the various treatments.

the 3 most important plant species (in terms of average cover) in each of the lifeform categories used.

The history of the treatments is summarized in Figure 1. Pre-fire vegetational and ground surface data were collected in 1981 within 4 original macro-plots used for another study (Hassan and West 1986). Establishment of a new well following the fire made a previously unwatered and lightly grazed portion of the 4,700 ha pasture, of which the study site is in the northwestern corner, accessible to cattle grazing. In order to opportunistically observe the changes in vegetation after fire, with and without the concomitant press-type (Tilman 1988) effect of livestock grazing, the 4 original macro-plots were separately fenced and 2 storage gauges for crop-year (1 September to 30 June) precipitation were established within 2 of the 4 exclosures within the burned and ungrazed treatment (Fig. 1).

\section{Treatments}

\section{Burned \\ and \\ Ungrazed}

\section{Burned}

and

Grazed

\section{Unburned and Grazed}

Additional macro-plots were established outside of the exclosures on the same ecological site to conduct an ad hoc "experiment" on vegetation dynamics in burned and unburned patches under grazed conditions (Fig. 1). Large enough unburned patches on the same ecological site were, unfortunately, unavailable to also fence and thus balance the design. Monitoring to support adaptive resource management will, however, require compromises between the scientists' need for experimental rigor with managers' needs for timely decision making (Szaro 1999, Thomas and Birchfield 2000).

All available treatments were replicated (Fig. 1), although numbers of replicates varied with the opportunities available. The study area had probably been lightly grazed in winter by sheep several decades before the wildfire event. The owners during the early part of our study period, however, leased the land only for cattle use. Neither the owner or leasee were willing to provide specifics of the grazing arrangement. We, therefore, can provide only qualitative impressions that there were usually "moderate" levels of grazing on the areas outside the fenced exclosures. Livestock grazing prior to collection of data would have a negative impact on the amount of plant cover remaining in the unfenced plots. Also there were some years late in the time series when cattle had not used the areas around the exclosures at all. These less frequent circumstances will be pointed out in the discussion of results. The pre-burn rangeland at this site was considered to be in "high good" (late seral) condition in 1981 by conventional methods (West and Hassan 1985).

The 4 exclosures (burned and ungrazed) and the unfenced, burned and grazed plots measured $20 \mathrm{~m}$ by $50 \mathrm{~m}$. Four exclosures (each $20 \mathrm{~m}$ by $50 \mathrm{~m}$ in size) were fenced during the fall of 1981 on comparable segments of the largely burned ballena. These constituted the 4 replicates of the burned and ungrazed treatment. Four other areas of $20 \mathrm{~m}$ by $50 \mathrm{~m}$ size in adjacent locations on similar terrain were also marked out at that time. These involved the burned and grazed treatment. Both of these treatments constituted subsamples of the larger available burned areas. The rarer unburned and grazed patches had to be sampled by three, $20 \mathrm{~m}$ by $20 \mathrm{~m}$ macro-plots and occupy most of the "islands" left within the mostly burned ballena. Five years following initiation of the study, some of the area outside the fenced exclosures was chained by the owner to topple scattered, firekilled juniper snags. This activity seriously altered 1 of the unburned and grazed replicates and further sampling was not done there.

A second wildfire occurred on a subset of the original plots before the 1987 data collection. However, because of a drought (Fig. 2) and consequent lack of continuous fine fuel, the effects of that fire were very patchy. From yearly photographs taken at permanent points and field journal notes, it appeared that Exclosures \#2 and \#3 were partially impacted, Exclosure \#1 escaped entirely, and Exclosure \#4 was completely reburned. Effects of the second fire on the vegetation were no longer either visually or statistically discernable the year following its occurrence in early July 1987. None of the grazed plots were impacted by the 1987 fire. In 1996, shortly after data collection, 1 of the unburned and grazed plots was burned, and so lost for further comparisons. 


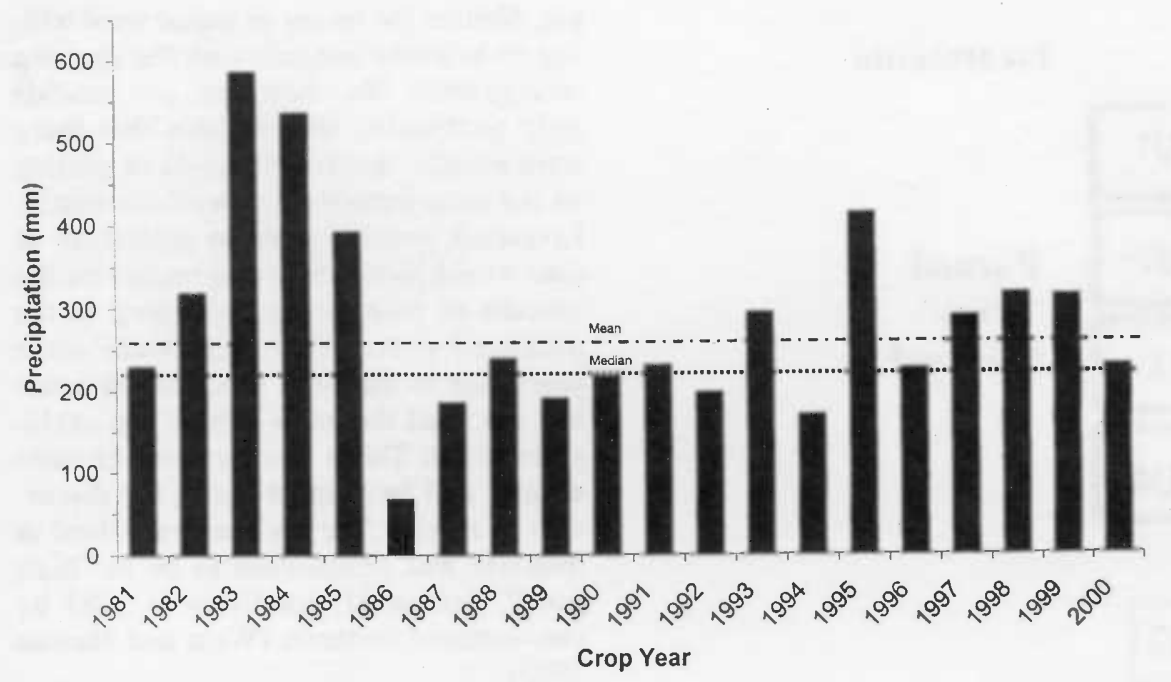

Fig. 2. Total crop-year (Sept. 1-June 30) precipitation $(\mathrm{mm})$ at the study area, 1981-2000. Average of two storage gauges, except $\mathbf{1 9 8 1 - 3}$ and 1988 when gauges were vandalized and an estimate was made by correlation with the Scipio station located $26 \mathrm{~km}$ to the SSE at $1,615 \mathrm{~m}$ elevation, $\mathrm{r}^{2}=0.67$

Both cover and end-of-growing season aboveground plant standing crop data were collected in 1982 (West and Hassan 1985). The latter was time-consuming, and if repeated annually, would have severely altered the vegetation on these relatively small macro-plots. Thus, only the cover in the topmost layer in the sward was estimated after 1982 in all plots. Canopy cover data are also more easily related to remotely-sensed imagery than phytomass. Canopy cover data were rapidly and non-destructively collected, using a gimbaled point technique (Winkworth and Goodall 1962), near the end of each growing season (third week of July). One hundred stations, from random starting points for 4 stepped off transects, were visited per macro-plot, and readings interpreted as percentage canopy cover of the current year's plant growth. Bare soil, gravel, rock, microphytes (moss + lichen), standing dead and litter were also enumerated where no live plants occurred directly above a point (sampling station). These sample numbers were considered adequate to detect changes in total community cover and cover classes greater than $3 \%$, through duplicate sampling 1 day apart in 1993 (Hosten 1995). Treshow and Allan (1985) employed similar numbers of subsamples for comparable vegetation.

In addition to graphing cover over time for total live and dead cover, growth form groups and species composition in each plot, ordination diagrams were used to discern temporal trends in total canopy cover-weighted plant community species composition within each replicate of each ungrazed exclosures, 1981-2000. time, total lengths of the time trajectories, numbers of crossovers, and directions of the yearly segments from the centroid. The SSH multi-dimensional scaling was chosen because it produces a measure of adequacy of fit to the scattergram termed "stress" (Faith et al. 1987). "Stress" is analogous to distances of points from the regression line in a least squares sense (Dillon and Goldstein 1984, p. 129). The values of "stress" potentially range from 0 to 1.0 , but points with "stress" values above 0.2 are considered unreliable (Dillon and Goldstein 1984) and thus not discussed here. Discrete clusters of points in different quadrants of ordination space would be taken as evidence of alternate stable states. Closely clustered points [separated by distances shorter than those expected by a combination of sampling error and those due to climatic fluctuation (Rabotnov 1974)] would be taken as evidence of no ecologically significant change in species or lifeform composition.

Data bearing on the classical static notion of stability could be gathered only on the burned and ungrazed treatment because the chronic impact of livestock grazing occurred outside these 4 exclosures. The degree of return to pre-fire plant community composition was ascertained from both graphs of cover by lifeforms and from ordination diagrams by visually comparing the placement of ordination points against a background representing ordination of all plots during all years including 1981. Comparison of vegetation change between all of the treat-

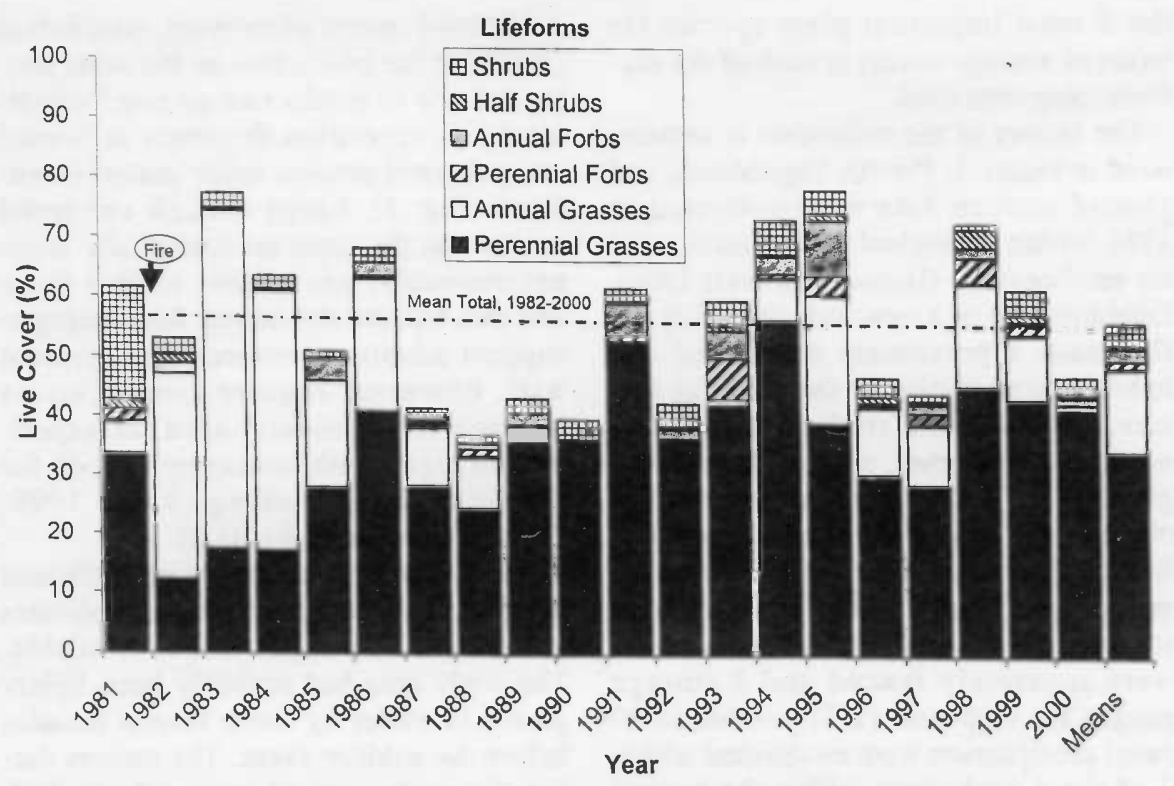

Fig. 3. Total and growth form canopy cover due to live plants within the burned and 


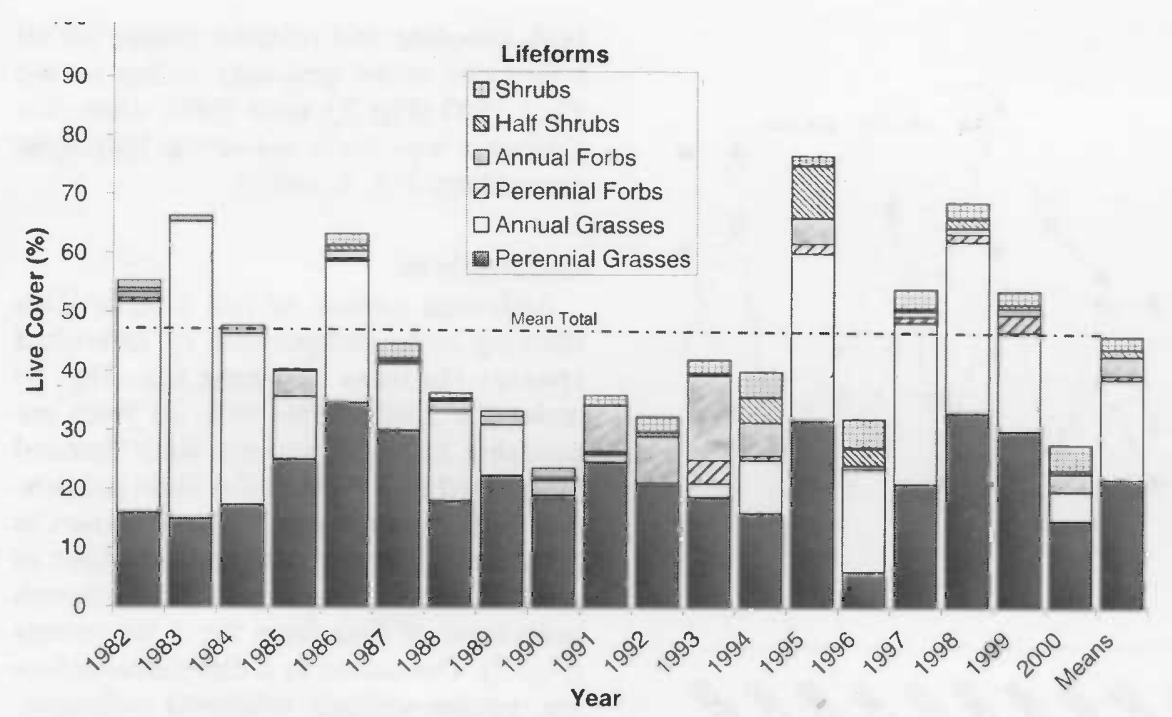

Fig. 4. Total and growth form canopy cover due to live plants within the burned and grazed macro-plots, 1982-2000

ments could be legitimately done with 1982 and older data because ordination space is flexible and relational, changing as data are added or subtracted (Dillon and Goldstein 1984). The placement of data points representing plots outside the exclosures, where cattle usually grazed, were compared to those inside the exclosures to determine possible additive effects of grazing and the interactions between burning and grazing.

While the graphical and ordination approaches helped us to visualize the important changes in vegetation within these plots over time, we also needed a means of deciding whether the differences observed had statistical significance. Accordingly, commercial statistical software packages were used; JMP® was the basis for regression, and SYSTAT ${ }^{\circledR}$ for testing ANOVA models. To address the possibility of lack of independence between years (serial correlation), we used a general linear mixed model for longitudinal data incorporating each macroplot as a block (accommodating variability among them) and explicitly accounting for the covariance among repeated measures within a macroplot (Verbeke 1997). A $5 \%$ probability for false separation among least square means was the chosen level of statistical significance.

\section{Results and Discussion}

\section{Mean Total Cover}

Mean total cover due to living plants within the four burned and ungrazed exclosures averaged $57 \%$, but varied between $37 \%$ and $79 \%$ over the 20 years grazed macro-plots, 1982-2000. in 1997, 1999, and 2000.

Mean total live cover in the unburned and grazed plots (Fig. 5) followed similar trends with the average cover $(47 \%)$ and maxima similar $(68 \%$, in 2 different years), whereas the minimum was greater (37\%) than the other grazed treatment.

\section{Shrub Cover}

Prior to the fire of 1981 , shrubs, which were mostly Wyoming big sagebrush (West and Hassan 1985), constituted 32\% of live plant cover on the 4 burned and ungrazed macro-plots (Fig. 3). The unburned and grazed remnants had 22 to $26 \%$ relative shrub cover for the first 3 years following the 1981 fire (Fig. 5). That proportion increased only slightly over the next 17 years (Fig. 5). The shrub cover increase on the burned areas was mainly due to Mormon tea. This shrub has shown several periods of growth (sometimes exceeding its pre-burn cover about twofold) and diminishment that were not always synchronous in the 3 treatments (Fig. 6). Artemisia has been slow to reestablish at our burned locations. The return of sagebrush at this sagebrush semidesert (West 1983) site is much slower following fires than in sagebrush steppe (Bunting 1984, Britton and Clark 1984, West 2000). As Treshow and Allen (1985) found for another sagebrush semi-desert site in Utah, shrub cover varied little during the period of study on the unburned but grazed plots (Fig. 5). The dominant Wyoming big sagebrush is a deep rooted evergreen known not to vary as much as herbaceous species in response to drought (Passey et al. 1982).

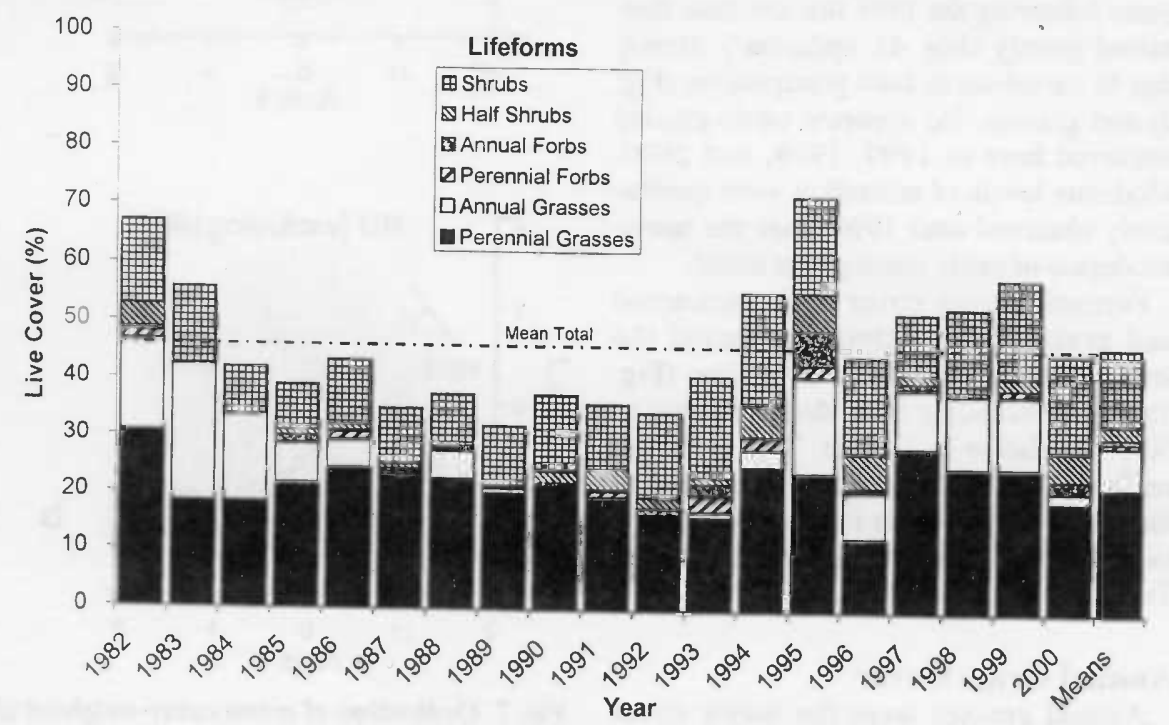

Fig. 5. Total and growth form canopy cover due to live plants within the unburned and 


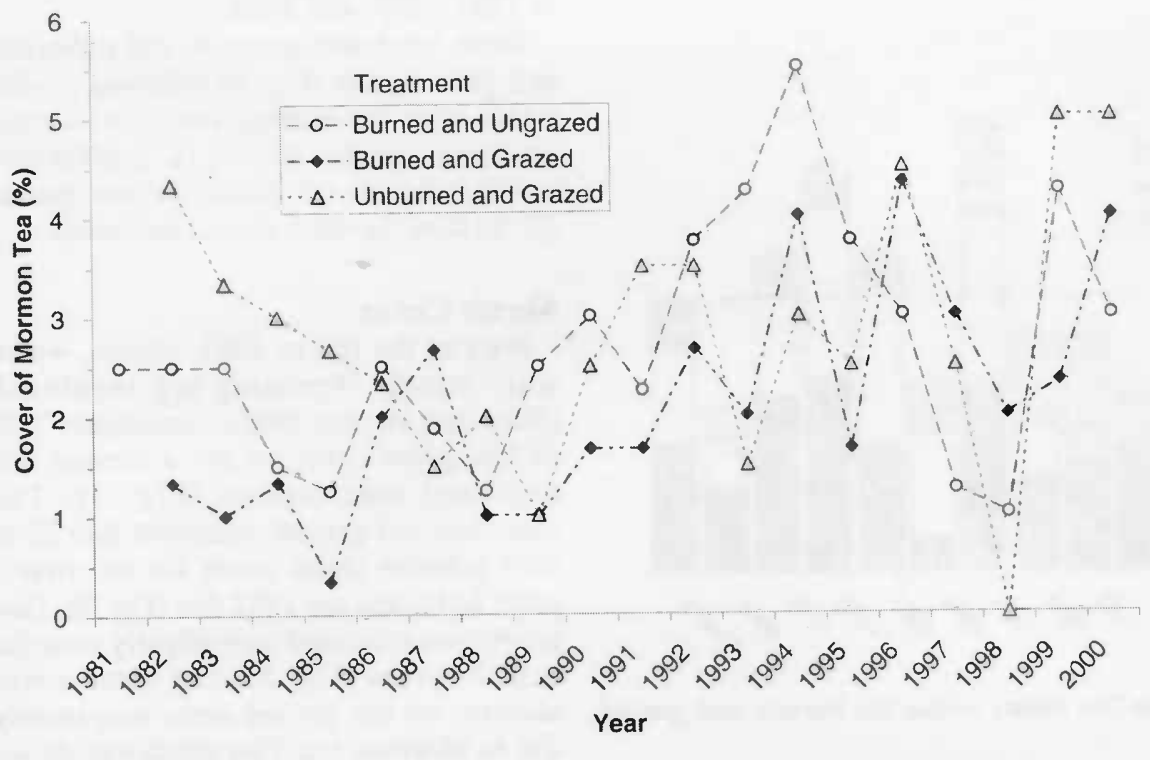

Fig. 6. Mean total canopy cover due to Mormon tea observed in the three treatments from 1982-2000.

\section{Perennial Grass Cover}

Perennial grasses constituted about $32 \%$ cover (55\% of the relative live cover) in 1981 before the first fire (Fig. 3). After an initial large reduction due to the fire, relative cover of the perennial grasses in the burned and ungrazed treatment increased steadily until 1994 when the second drought during the study period began (Fig. 2). Absolute cover of perennial grasses also increased until 1994 in this treatment (Fig. 3). Since 1994 perennial grass cover has fluctuated and other perennial life forms (half-shrubs, forbs) have increased, both in relative and absolute senses.

Perennial grass cover on the burned and grazed plots increased during the first 5 years following the 1981 fire and then fluctuated greatly (Fig. 4), apparently mainly due to variations in both precipitation (Fig. 2 ) and grazing. No apparent cattle grazing occurred here in 1997, 1999, and 2000. Moderate levels of utilization were qualitatively observed until 1996 when the heaviest degree of cattle grazing was noted.

Perennial grass cover in the unburned and grazed macro-plots has varied the least of any growth form over time (Fig. 5 ), never exceeding $30 \%$ absolute cover or $50 \%$ of relative live cover. This is apparently a result of the continuing control of the micro-environment in these patches by sagebrush (Pierson and Wight 1991, Treshow and Allan 1985).

\section{Annual Grass Cover}

Annual grasses were the major cover component on all burned macro-plots from 1982 to 1984 (Figs. 3 and 4). Their
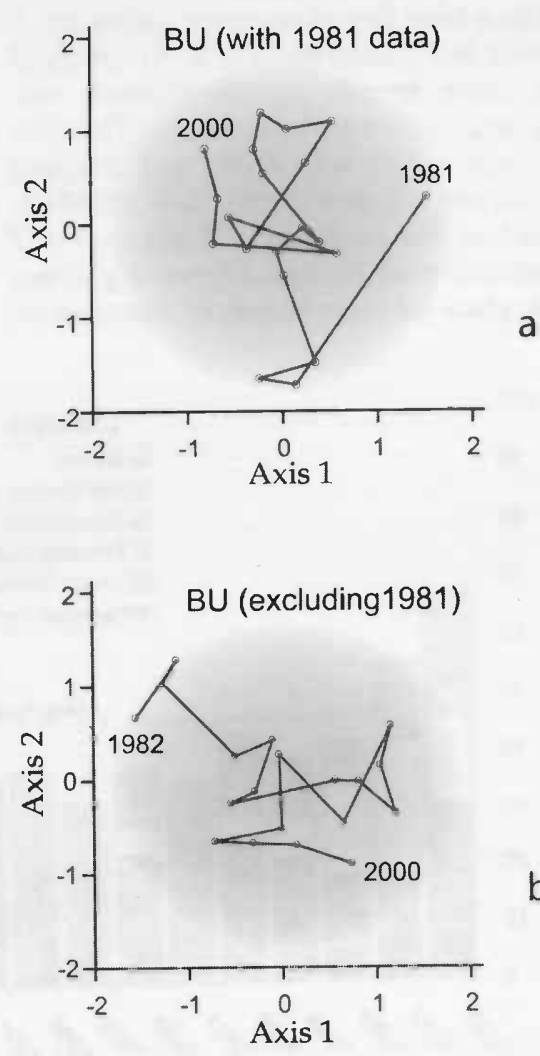

both absolute and relative senses on all treatments in the generally wetter period since 1993 (Fig. 2), until 2000, when precipitation was again below the long term mean (Figs. 2, 3, 4, and 5).

\section{Ordinations}

Although copies of full tabular data showing cover composition by individual species (besides Mormon tea, Fig. 6) under the 3 treatments over 20 years are available from the authors, their demand for printed space precludes their publication here. Accordingly, we have chosen to graphically show the overall changes in plant community composition through ordination of data from the 3 treatments (Fig. 7). Ordination is a dimension-reducing, pattern-seeking, relational technique. That is, the dimensions of covers of all individual species or growth form categories are reduced to 2 dimensions (axes) so the results of the multivariate analyses can be viewed on paper.

To test the sensitivity of ordination to differences in data input, we compared the SSH ordinations of the burned, ungrazed treatment with and without the 1981 preburn data. This created trajectories which started and stopped in differing quadrants
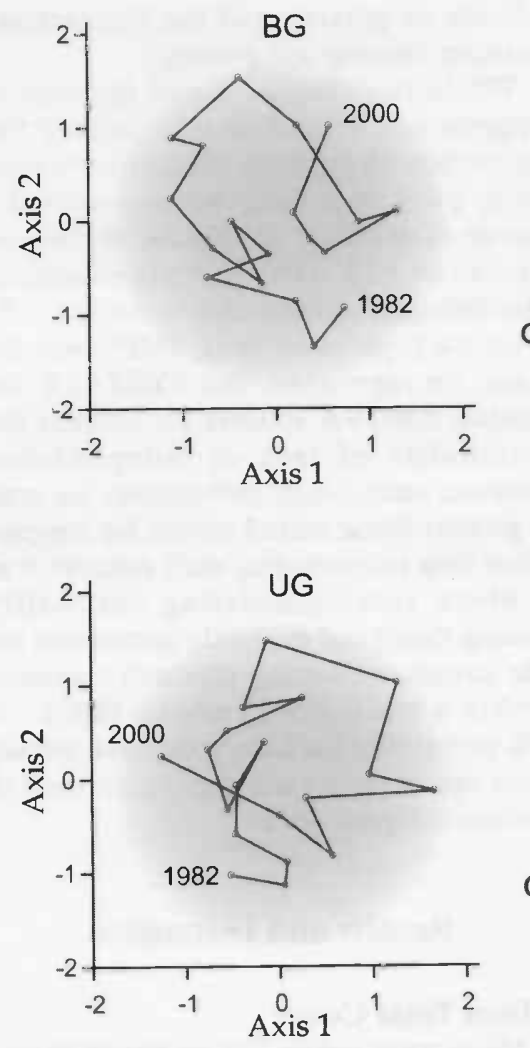

Fig. 7. Ordination of mean cover-weighted plant species composition in the three treatments from 1982-2000. The gray area represents the overall area within which points were found through ordinations of individual macro-plots. 
Table 2.Characteristics of ordination pathways. Mean values for each of three treatments. Lengths are relative units, positive degrees of change are clockwise, negative are counter clockwise, quadrant $\mathrm{I}=0-90^{\circ}, \mathrm{II}=91-179^{\circ}, \mathrm{III}=180-26^{\circ}, \mathrm{IV}=270-359^{\circ}$

\begin{tabular}{lcccccccc}
\hline \hline & $\begin{array}{c}\text { Mean } \\
\text { segment }\end{array}$ & $\begin{array}{c}\text { Total } \\
\text { path }\end{array}$ & $\begin{array}{c}\text { Number } \\
\text { of }\end{array}$ & \multirow{2}{*}{$\begin{array}{c}\text { Net } \\
\text { degrees of }\end{array}$} & \multicolumn{4}{c}{$\begin{array}{c}\text { Frequency of Points } \\
\text { in Quadrants }\end{array}$} \\
\cline { 7 - 9 } Treatment & length & length & crossovers & change & I & II & III & IV \\
\hline $\begin{array}{c}\text { Burned, } \\
\text { Ungrazed }\end{array}$ & 2.8 & 27 & 4 & -287 & 2 & 7 & 4 & 6 \\
$\begin{array}{c}\text { Burned, } \\
\text { Grazed }\end{array}$ & 3.0 & 28 & 3 & 523 & 4 & 6 & 5 & 4 \\
$\begin{array}{c}\text { Unburned, } \\
\text { Grazed }\end{array}$ & 3.5 & 33 & 3 & 556 & 3 & 6 & 4 & 6 \\
\hline
\end{tabular}

(Figs. 7a and $b$ ). The pre-burn vegetation was sagebrush dominated (West and Hassan 1985) and had a longer list of plant species present than in any other subsequent year. We, thus, confirmed the importance of only using data collected between 1982 and 2000 when comparing ordinations of data from the 3 treatments.

The comparison of 1982-2000 successional trajectories in ordination space was made with the aid of 5 enumerations (Table 2). The burned, ungrazed treatment showed the shortest total length of trajectory path and shortest average length of steps between years. Counter-clock-wise tracking canceled out most of the clockwise movement and created 4 crossovers, the most observed in any treatment. Most of the movement in the burned, ungrazed trajectory was in Quadrants II and IV (Table 7b).

The burned and grazed treatment showed an intermediate total length of pathway and mean for segment lengths between years (Table 2, Fig. 7c). The high positive net degrees of change fortifies the visual impression of a tendency for this trajectory to spiral clockwise. No particular quadrants were favored. The unburned, grazed treatment showed the longest total trajectory length and thus, also the greatest mean segment length (Table 2). This treatment also showed the strongest evidence of a clockwise twist to the time trajectory. Quadrants II and IV were favored in this treatment. The number of crossovers in the trajectories for the different treatments were very similar.

From inspections of ordinations, we found it difficult to conclude that the vegetation was stable in any of the treatments. The only consistent result was the pronounced protrusion into the second quadrant on the 2 grazed treatments during 1996 , the year with the greatest degree of forage utilization by cattle. Thus, ordination did not portray secondary successional patterns in easy to interpret ways. While the literature generally favors ordination as a way of compressing data on compositional change, this study demonstrated that where total species lists are short and temporal changes are drastic, differences in a few species with episodic occurrence (e.g. Mormon tea, cheatgrass) can result in very different pathways of secondary succession being expressed.

\section{Regression Analyses}

Another, simpler way to make comparisons of vegetational changes over time between treatments is to graph scatter plots, visually compare, and regress the time courses of life form cover by treatment. While we did this for all life form groups, the most notable patterns were observed for total perennials (Fig. 8) and perennial grasses (Fig. 9). This was true regardless of whether all the data in a treatment were combined (Figs. 8 and 9) or analyzed replication by replication (not shown). Both the linear regressions and statistical analysis of their slopes (Underwood 1997) showed there has been a significantly $(\mathrm{p}<.05)$ faster increase of perennials in the burned and ungrazed than the other 2 treatments. No significant change in perennial cover was detected in either type of grazed treatment. The drought of 1986-92 (Fig. 2) had no consistent effect on these patterns. Perennial grasses were the major contributors to the total perennial cover in the burned treatments, thus, when they were considered alone (Fig. 9), it was no surprise that the burned and ungrazed treatment showed perennial grass cover increased at the most rapid rate and sustained the greatest average cover of these plants at the end of the study.

Another interesting feature of the regression analyses was that while there was no evidence from linear fits that either total perennial (Fig. 8) or perennial grass (Fig. 9) cover had yet reached the maximum in the burned and ungrazed treatment, many nonlinear fits were tried but a $4^{\text {th }}$ order nonlinear fit of the combined data did increase the $\mathrm{R}^{2}$ about $50 \%$ and indicated a leveling off since about 1993. This asymptotic response is to be expected in ungrazed vegetation of this region (Passey et al. 1982, Sneva and Britton 1983). We also analyzed these data with each replicate as a data point. These results showed a similar pattern, with an increased variance, but are too visually cluttered to reproduce effectively here.

The drought period of 1986-92 (Fig. 2) did not reduce the cover of perennial grasses, but did reduce the cover of annual grasses, regardless of treatment (Fig. 3, 4, and 5). Annual grasses, however, have rebounded comparatively more since the drought on the burned plots, both grazed and ungrazed (Figs. 3 and 4). This conclusion is further supported by plotting the relationship of perennial grass cover to annual grass cover by treatment over all years, irrespective of the time course (Fig. 10). In the ungrazed macro-plots, there was a clear tradeoff of more perennial grass as annual grasses declined and vice versa, a situation not found in either the burned and grazed or unburned and grazed macro-plots $(\mathrm{p}<.05)$ (Fig 10).

\section{Analysis of Variance (ANOVA)}

Another common way to compare the effects of treatments is through ANOVA (Underwood 1997). Total perennial cover, (Fig.11a), was similar in the exclosures (burned and ungrazed) and the unburned and grazed treatment, but lower $(\mathrm{p}<.01)$ in the burned and grazed treatment. Annual grass cover (Fig.12b) was significantly $(\mathrm{p}<0.05)$ lower in the unburned and grazed treatment. The largest separation among life form groups was for perennial grasses (Fig. 11c), where the repeated measures ANOVA confirmed that the burned and ungrazed treatment had significantly higher cover $(\mathrm{p}<.001)$. This result supports the earlier discussion of the temporal pattern of increases in the perennial grass component (Fig. 3 and 9).

\section{Conclusions}

This long-term study has found several results that are counter to the expectations derived from earlier, and mostly shorterterm investigations reported in the literature (West and Young 2000). First of all, once cheatgrass came to dominate in the first few years following the 1981 wildfire, we expected this widespread invader grass to stay abundant thereafter. Instead, the perennial grasses recovered vegeta- 

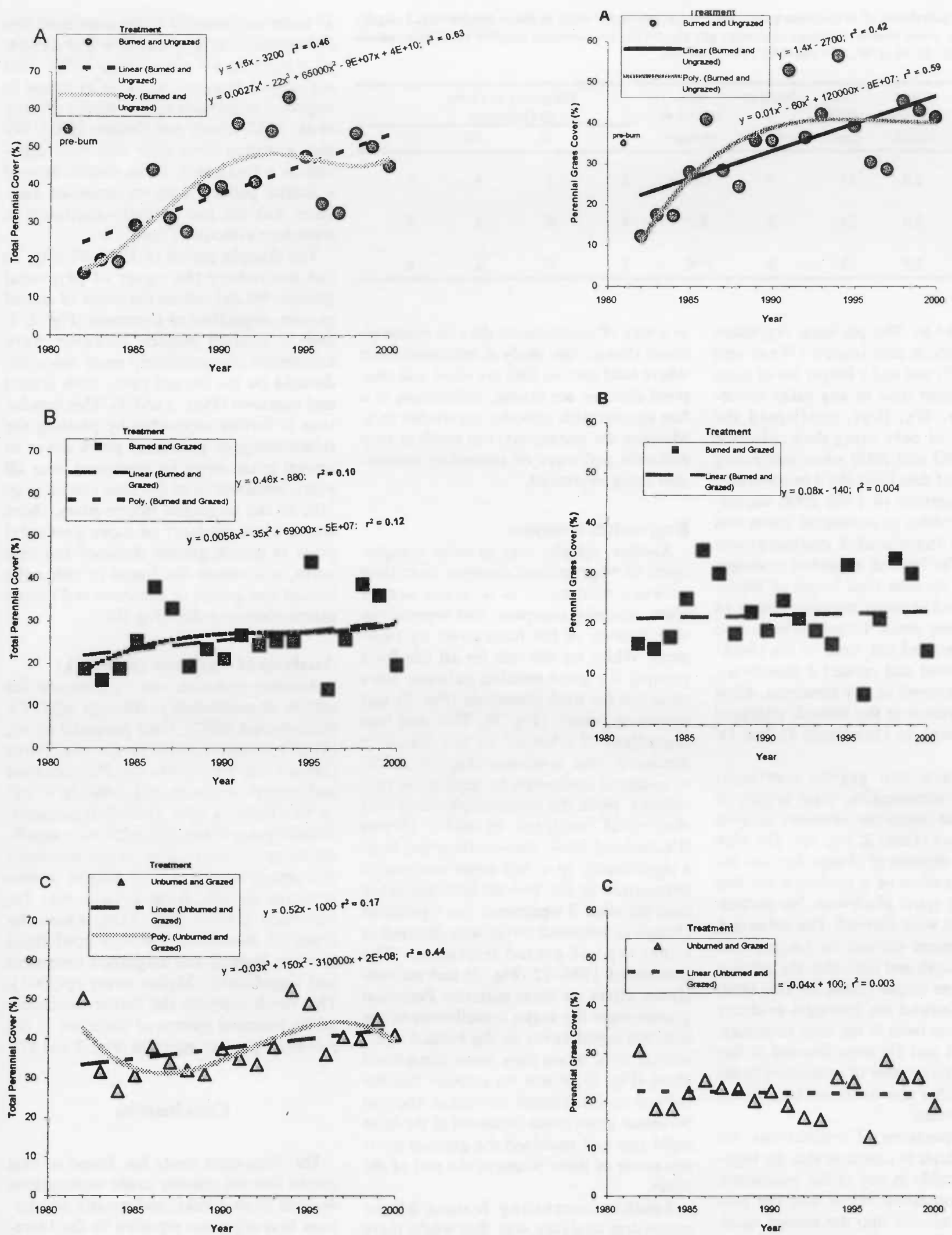

Fig. 8. Regressions of mean total perennial canopy cover observed in the three treatments from 1982-2000, plus 1981 mean pre-fire cover for the burned and ungrazed exclosures. Poly $=$ fourth order polynomial fit.

Fig. 9. Regressions of mean total perennial grass canopy cover observed for each of the three treatments from 1982-2000, plus 1981 mean prefire cover for the burned and ungrazed exclosures. Poly = fourth order polynomial fit. 

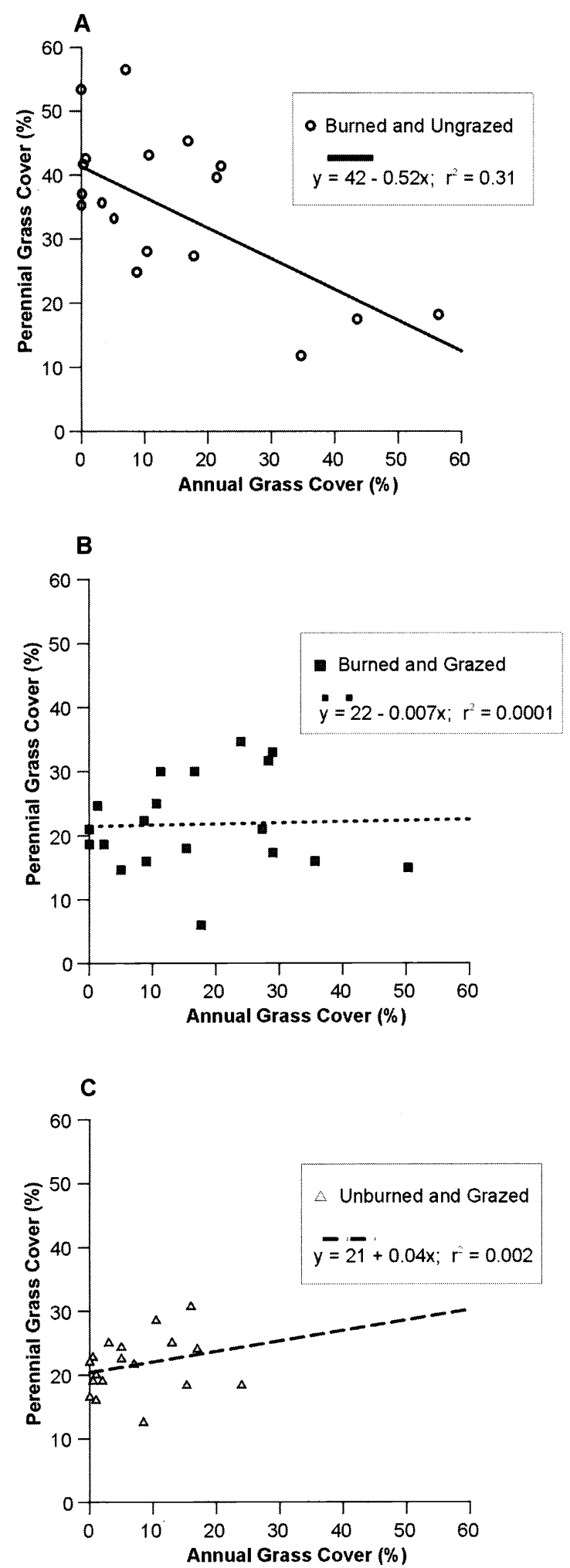

Fig. 10. Cover of perennial grasses in relation to cover of annual grasses by treatment over all years.

tively and came to dominate plant cover ever since, especially in the ungrazed macro-plots. Furthermore, cheatgrass and other annuals almost became locally a new annual-dominated state, as has occurred often elsewhere (West and Young 2000), has not been crossed at the site studied here.

The reinvasion of sagebrush and juniper following the wildfire was unexpectedly slow. Although several surges of Mormon tea recovery and subsequent dieback were detected, that species also recovered vegetatively. Wyoming big sagebrush and Utah juniper must return through seed dispersal. Even though unburned patches with mature sagebrush and juniper have persisted nearby (less than $50 \mathrm{~m}$ away), sagebrush seedlings are few, and juniper seedlings undetected, so far, in the burned macro-plots. This would support the conclusion that bunchgrasses were probably more dominant in the past (Trickler and Hall 1984) before the fire regime was altered (West 2000). The potential natural community for this site, however, is expected (Trickler and Hall 1984) to have about $50 \%$ cover by woody species.

Looking at the results of our analyses in total, not just by species or growth form groups, suggests that permanent changes in state have not yet occurred here, regardless of treatment. We are, however, using the definitions of Stringham et al. (in press), where changes in state are what happens when thresholds of permanent change in the abiotic environment occur, usually following accelerated soil erosion. Except for the obvious negative interactions between annuals, particularly cheatgrass, and all perennials, primarily the bunchgrasses, we see only loose linkages between species and life form groups in vegetational recovery following fire and subsequent sporadic cattle grazing of the unfenced plots.

We expected ordination to be the most revealing method for interpreting speciesoriented vegetation change. We found, however, that the type of ordination we used is very sensitive to changes in the input data, low species numbers and the dramatic shifts in this vegetation over time. Graphic analysis was more easily interpretable than ordination. Regression and ANOVA also had some utility in distinguishing between treatments with known statistical significance. All the different methods of analysis used showed unique and partial views of results that complement one another.

The owner of the privately-held land upon which we conducted this study expects to continue to derive some income from livestock grazing. Thus, to him, the vegetation in the exclosures is not the reference condition or what he expects to see 

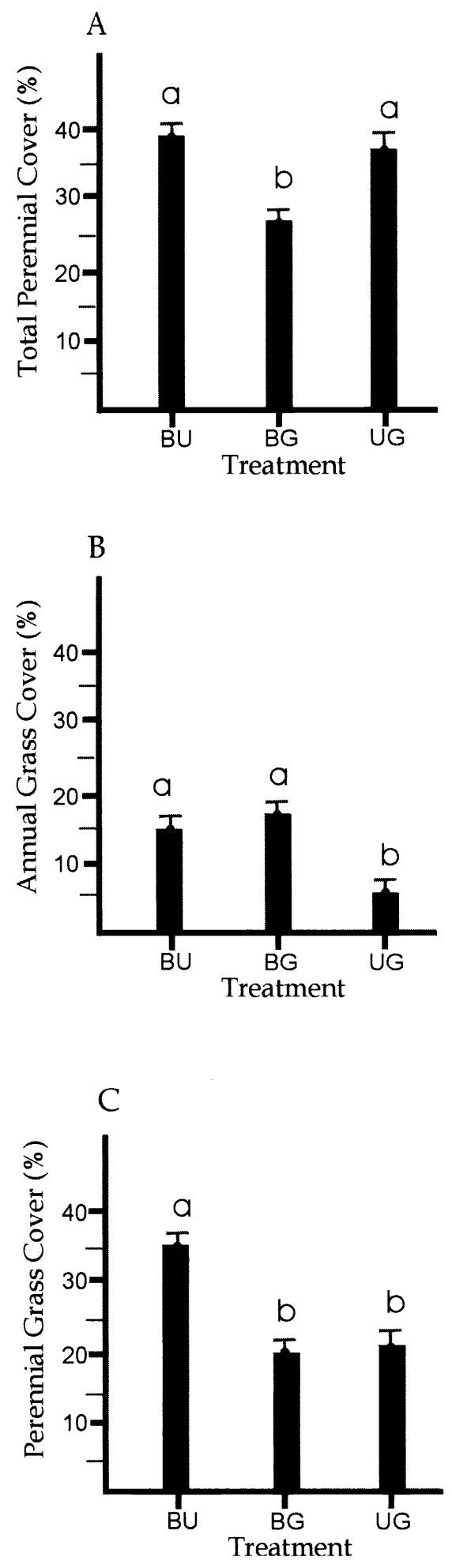

Fig. 11. Least square means and standard error bars for (a) total perennial cover, (b) perennial grass and, (c) annual grass cover in the three treatments. Differing lower case letters over the bars indicate statistical significant differences at $\mathbf{p}<\mathbf{0 . 0 5}$. Different treatments designated by same code as used in Figure 1. across all portions of the pasture where the Upland Shallow Loam (Juniper-Pinyon) Ecological Site occurs. On the nearby federally owned (BLM) land with the same ecological site, livestock production is not necessarily the sole or primary objective. Soil protection and wildlife interests rank higher there. In those circumstances, the vegetation within the exclosures have higher value as references for judging condition (Szaro 1999).

It should be noted that our study area is not typical of most sagebrush semidesert (West 1983) sites in the eastern Great Basin. The ballena on which the data were taken is a remnant of an alluvial fan that has undergone considerable dissection (Peterson 1981). In other words, the land upon which the plots occur is very old. This is shown by the continuous accumulation of the petrocalic layer (Boettinger et al. 1997) with only a shallow surface horizon above. Thus, because of this great age of the soil, most of the nutrients have probably either long ago left the site or are occluded on the calcium carbonate (phosphorus in particular).

In 1981, we found sagebrush dominated vegetation with remnants of herbaceous perennials. The wildfire destroyed the sagebrush and widely scattered juniper over most of the ballena. While cheatgrass dominated in the first few years following the fire, the perennial grasses recovered vegetatively and have come to dominate since, especially in the ungrazed exclosures. We speculate that such an unexpected result (the transitive role of cheatgrass) can only be expected on sites with low stores of and capacities to fix nitrogen and other critical elements to plant growth.

In summary, we have found the collection and analysis of interannual vegetational data aggregated and analyzed in various ways in this opportunistic "experiment" to be illuminating of the issues involved in modernization of our approaches to applying ecology to determine rangeland condition and trend. While our specific results apply only to 1 ecological site, we feel we have demonstrated with minimal effort (4 person days per year of field work), the usefulness of longterm data sets in guiding acceptance or rejection of some of the general suggestions in the literature as to how to organize data for and interpret the results of monitoring to guide management decisions. We recommend that others look for similar opportunities elsewhere.

\section{Literature Cited}

Belbin, L. 1992. PATN: Pattern analysis package users guide. Commonw. Scientific and Indust. Res. Organ., Div. of Wildlife and Rangelands Res., Canberra, ACT, Australia.

Boettinger, J.L., J.A. Doolittle, N.E. West, E.W. Bork and E.W. Schupp. 1997. Nondestructive assessment of rangeland soil depth to petrocalcic horizon using electromagnetic induction. Arid Soil Res. and Rehabilitation. 11:375-390.

Botkin, D.B. 1990. Discordant harmonies. Oxford University Press, New York, N.Y.

Bunting, S.C. 1984. Fires in sagebrush-grass ecosystems: successional changes, p. 7-11. In: K. Sanders and J. Durham (eds.) Rangeland fire effects: a symposium. U.S Dept. Interior Bureau of Land Manage., Boise, Ida.

Britton, C.M. and R.G. Clark 1984. Effects of fire on sagebrush and bitterbrush, $p$. 22-26. In: K. Sanders and J. Durham (eds.) Rangeland fire effects: a symposium. U.S Dept. Interior, Bureau of Land Manage., Boise, Ida.

Burrows, C.J. 1990. Processes of vegetation change. Unwin Hyman, London.

Crowley, P.H. 1992. Density dependence, boundedness, and attraction: Detecting stability in stochastic systems. Oecologia 90:246-254

Dillon, W.R. and M. Goldstein. 1984. Multivariate analysis: methods and applications. John Wiley and Sons, New York N.Y.

Faith, D.P., P.R. Minchin, and L. Belbin. 1987. Compositional dissimilarity as a robust measure of ecological distance. Vegetatio 69:57-68.

Friedel, M.H. 1991. Range condition assessment and the concept of thresholds: a viewpoint. J. Range Manage. 44:422-426.

Hassan, M.A.and N.E. West. 1986. Dynamics of soil seed pools in burned and unburned sagebrush semi-deserts. Ecol. 76:269-272.

Hosten, P.E. 1995. Assessing the relative utility of models of vegetation dynamics for the management of sagebrush steppe rangelands. Ph.D. Diss., Utah State Univ., Logan, Ut.

Hosten, P.E. and N.E. West. 1994. Cheatgrass dynamics following wildfire on a sagebrush semidesert site in central Utah, p. 56-62. In: S.B. Monsen, and S.G. Kitchen (compilers), Proc. Symposium Ecology And Management Annual Rangelands, U.S. Dept. Agr. Forest Service, Intermountain Res. Sta., Gen. Tech. Rep. INT-GTR-313, Ogden, Ut.

Joyce, L.A. 1993. The life cycle of the range condition concept. J. Range Manage. 46:132-138.

Lauenroth, W.K. and W.A. Laycock (eds.) 1989. Secondary succession and the evaluation of rangeland condition. Westview Press, Boulder, Colo.

Laycock, W.A. 1991. Stable states and thresholds of range condition on North American rangelands-A viewpoint. J. Range Manage. $44: 427-433$ 
Laycock, W.A. 1995. New perspectives on ecological condition of rangelands: can state and transition or other models better define conditions and diversity, p. 140-164. In: L. Montes and G.E. Olivia (eds.) Proceedings International Workshop on Plant Genetic Resources Desertification and Sustainability. Centro Regional Patagonia Sur, INTA-EEA, Rio Gallegos, Santa Cruz, Argentina.

Lewontin, R.C. 1969. The meaning of stability, p. 13-22. In: G.M Woodwell and H.H. Smith (eds.), Diversity and stability in ecological systems. Brookhaven Sym. Biology 22. Brookhaven National Laboratory, Upton, N.Y.

Passey, H.B., V.K. Hugie, E.W. Williams, and D.E. Ball. 1982. Relationships between soil, plant community, and climate on rangelands of the Intermountain West. U.S. Dept. Agr. Soil Cons. Serv., Tech. Bull. 1669.

Pierson, F.B. and J.R. Wight. 1991. Variability of near surface temperature on sagebrush rangeland. J. Range Manage. 44:491-497.

Peterson, F.F. 1981. Landforms of the Basin and Range Province defined for soil survey. Nevada Agr. Exp. Sta. Tech. Bull. 28, Univ. Nevada, Reno, Nev.

Rabotnov, T.A. 1974. Differences between fluctuations and succession, p. 21-21. In: R. Knapp (ed.) Vegetation Dynamics. Handbook of Vegetation Science. Vol 8. W. Junk Publ., The Hague, Netherlands.

Scarnecchia, D.L. 1995. Viewpoint: The rangeland condition concept and range sciences search for identity: A system viewpoint. J. Range Manage. 48:181-186.
Sneva, F. and C.M. Britton. 1983. Adjusting and forecasting herbage yields in the Intermountain Big Sagebrush Region of the Steppe Province. Oregon Agr. Exp. Sta. Bull. 659. Oregon State Univ., Corvallis, Ore.

Stringham, T.K., W.C. Krueger, P.J. Meiman and $P$. Shaver, in press. States, transitions, and thresholds: Further refinement for rangeland applications. Addendum to National Range and Pasture Handb. Natural Resources Cons. Service, Grazing Lands Tech. Institute, Fort Worth, TX.

Szaro, R. 1999. Monitoring and evaluation, 223-230. In: N.C. Johnson, A.J. Malk, R.C. Szaro, and W.T. Sexton (eds.), Ecological stewardship, Vol. I, Elsevier, Amsterdam.

Tilman, D. 1988. Plant strategies and the dynamics and structure of plant communities. Princeton Univ. Press, Princeton, N.J.

Thomas, J.W. and J. Birchfield. 2000. Science, politics and land management. Rangelands $22: 45-51$.

Treshow, M. and J. Allan. 1985. Uncertainties associated with the assessment of vegetation. Environ. Manage. 9:471-478.

Trickler, D.L. and D.T. Hall. 1984. Soil survey of Fairfield-Nephi area Utah. U.S. Dept. Agr. Soil Conservation Service, Salt Lake City, Ut.

Underwood, A.J. 1997. Experiments in ecology. Cambridge Univ. Press, Cambridge, U.K.

Verbeke, G. 1997. Linear mixed models for longitudinal data, 63-155. In: G. Verbeke and G. Molenberghs (eds.). Linear Mixed Models in Practice: A SAS-oriented approach. Lecture Notes in Statistics. No. 126, Springer-Verlag, New York.
West, N.E. 1983. Great Basin-Colorado Plateau Sagebrush Semi-desert, p. 331-349. In: N.E. West (ed.) Temperate deserts and semi-deserts. Elsevier Sci. Publ., Amsterdam, Netherlands.

West, N.E. 2000. Synecology and disturbance regimes of sagebrush steppe ecosystems, $p$. 15-26. In: P.G. Entwistle et al., compilers, Proceedings: Sagebrush Steppe Ecosystems Symposium, Bureau of Land Management Publication No. BLM/ID/PT-001001+150 Boise, ID.

West, N.E. and M.A. Hassan. 1985. Recovery of sagebrush-grass vegetation following wildfire. J. Range Manage. 38:131-134.

West, N.E. and E.L. Smith. 1997. Improving the monitoring of rangelands. Rangelands 19:9-14.

West, N.E. and J.A. Young. 2000 . Intermountain valleys and lower mountain slopes, p. 255-284. In: M.A. Barbour and W.D. Billings (eds.). North American Terrestrial Vegetation, $2^{\text {nd }}$ ed. Cambridge Univ. Press, New York.

Westoby, M., B. Walker and I. Noy-Meir. 1989a. Opportunistic management for rangelands not at equilibrium. J. Range Manage. 42:266-274.

Westoby, M., B. Walker and I. Noy-Meir. 1989b. Range management on the basis of a model which does not seek to establish equilibrium. J. Arid Environ. 17:235-239.

Winkworth, R.E. and D.W. Goodall. 1962. A crosswire sighting tube for point quadrat analyses. Ecol. 43:342-343. 